УДК 336.733

DOI: $10.25140 / 2411-5215-2021-2(26)-124-133$

Максим Дубина, Наталія Островська, Ірина Мурашковська

\title{
ТЕОРЕТИЧНІ ПОЛОЖЕННЯ ФУНКЦІОНУВАННЯ РЕЙТИНГОВИХ АГЕНТСТВ НА РИНКУ КРЕДИТНИХ ПОСЛУГ
}

\author{
Maksym Dubyna, Natalia Ostrovska, Iryna Murashkovska \\ THEORETICAL PROVISIONS OF THE FUNCTIONING \\ OF RATING AGENCIES IN THE CREDIT SERVICES MARKET
}

У статті розглянуті теоретичні питання функиіонування рейтингових агентств на ринку кредитних послуг, зокрема, розглянуто сутність таких категорій, як «рейтинг», «кредитний рейтинг». Для иього було проаналізовано різні конщепиії дослідження змісту таких дефініцій. Також визначено та описано роль кредитних рейтингових агентств у розвитку фінансової системи країни, що було реалізовано через виокремлення та уточнення функиій цих установ. У статті також обтрунтовано важливість розвитку кредитних рейтингових агентств для функиіонування банківських та інших фінансових установ, забезпечення стабільності їх роботи та стійкості економіки до виникнення і розвитку кризових ситуацій у фінансовій системі краӥни.

Ключові слова: рейтинг; кредитний рейтинг; кредитне рейтингове агентство; кредитоспроможність; ринок кредитних послуг; фінансова система; фінансові установи.

Табл.: 3. Бібл.: 20.

Within the article, theoretical issues of the functioning of rating agencies in the credit services market, in particular, the essence of such categories as "rating", "credit rating" are considered. To do this, various concepts of studying the content of such definitions were analyzed. The role of credit rating agencies in the development of the country's financial system was also defined and described, which was implemeneted through the separation and clarification of the functions of these institutions. In addition, within the article, the importance of the development of credit rating agencies for the functioning of banking and other financial institutions, ensuring the stability of their work and the resilience of the economy to the emergence and development of crises in the country's financial system are substantiated.

Keywords: rating; credit rating; credit rating agency; creditworthiness; credit services market; financial system; financial institutions.

Table: 3. References: 20.

JEL Classification: G21

Постановка проблеми. Ринок кредитних послуг є важливою складовою розвитку фінансової системи країни. Реалізуючи надважливу функцію забезпечення економічних агентів необхідними їм для розвитку фінансовими ресурсами, окреслений ринок здійснює потужний вплив на активізацію господарських процесів у країні й тим самим формує умови для здійснення нових бізнес-проєктів, забезпечення зростання рівня соціальноекономічного розвитку населення. Таким чином, забезпечення ефективного функціонування такого ринку є об' єктивно необхідним чинником розбудови загалом ринку фінансових послуг, розвитку банківської системи та системи небанківських кредитних установ.

Проте ринок фінансових послуг за своєю сутністю є ринком високоризиковим і саме тому розвивається постійно в досить стохастичному та непередбачуваному економічному середовищі. Така ситуація обумовлює необхідність з боку органів державної влади, враховуючи макросистемну природу зазначеного ринку, постійно здійснювати нагляд за функціонуванням такого ринку, роботою кредитних установ, які виступають позикодавцями на ньому. Саме недостатній розвиток ринку кредитних послуг, хаотичний розвиток такого в умовах економічних криз, фінансової нестабільності в державі може привести до фінансових кризових ситуацій в країні. Враховуючи загальнонаціональний розвиток зазначеного ринку, деструктивні процеси одразу починають виникати в інших складових ринку фінансових послуг, галузях та сферах господарства країни.

Отже, враховуючи важливість ринку кредитних послуг для забезпечення стійкості економічної системи, забезпечення розвитку національного господарства, що впливає також на розвиток соціальної сфери [5; 6], на сьогодні вже розроблено та впроваджено низку різних механізмів для запобігання виникненню системних криз у межах такого ринку. Одним із таких механізмів є функціонування рейтингових агентств на ринку фінансових послуг.

(C) Дубина М. В., Островська Н. С., Мурашковська І. А., 2021 
ФІНАНСОВІ РЕСУРСИ: ПРОБЛЕМИ ФОРМУВАННЯ ТА ВИКОРИСТАННЯ

Рейтингові агентства та кредитні рейтингові агентства $є$ організаціями, які постійно здійснюють аналіз функціонування кредитних установ, їх клієнтів, особливо великих компаній та суб'єктів підприємницької діяльності. Завдяки роботі таких агентств кредит давці можуть більш точно визначати кредитоспроможність своїх майбутніх клієнтів та приймати виважені рішення щодо надання позик таким економічним суб'єктам. Відповідно, враховуючи сучасні, швидкозмінні процеси в розвитку всієї фінансової системи у світі, використання цифрових технологій у цій системі, кредитні рейтингові агентства, враховуючи постійно зростаючу транспарентність роботи їхніх клієнтів, мають змогу ще точніше визначати рівень ризикованості кредитних операцій і тим самим сприяти зниженню системного кредитного ризику в межах національної економіки, створювати передумов для ефективного розвитку ринку кредитних послуг [14; 15]. Саме тому питання функціонування кредитних рейтингових агентств у сучасному світі, їхньої ролі у розбудові фінансових систем країн стають актуальними. Відповідно поглиблення вимагають теоретичні та прикладні положення роботи таких установ.

Аналіз останніх досліджень і публікацій. Як уже зазначалося, питання дослідження теоретичних положень функціонування рейтингових агентств на ринку кредитних послуг є досить важливими 3 позицій забезпечення стабільності національної економіки, стійкості фінансової системи до нових загроз, а тому постійно перебувають у центрі уваги науковців. У вітчизняній науковій літературі дослідженню питань рейтингової оцінки діяльності фінансових установ присвячено праці таких вітчизняних науковців: М. Бабенко, В. Батковського, Т. Васильєвої, В. Вітлінського, І. Гумен, Л. Долінського, А. Жаворонка, Г. Карчевої, А. Незнамова, . Пшика, Г. Перерви, Р. Чорного та інших. Дослідженню ролі, проблематики функціонування, а також шляхів реформування діяльності кредитних рейтингових агентств присвячені праці західних економістів, а саме: П. Гавраса, Дж. Катца, А. Су, Кристофер Ф. Блюмфілд, В. Лексис, Д. Мак Нотон, Е. Рід, С. П. Роуз, Дж. Ф. Сінкі та ін.

Виділення недосліджених частин загальної проблеми. Однак, незважаючи на численні напрацювання вчених у сфері функціонування ринку кредитних послуг, роботи кредитних установ, питання розвитку та удосконалення діяльності кредитних рейтингових агентств залишаються актуальними. Це насамперед пов'язано як із трансформацією окресленого ринку в сучасних умовах становлення цифрової економіки, так і зі зміною моделей розвитку фінансових установ. Саме окреслене також вимагає зміни роботи кредитних рейтингових агентств і поступово також змінює всю індустрію кредитних рейтингові в усіх країнах, де активно розвивається ринок кредитних послуг. Це й зумовлює необхідність проведення систематичних досліджень у цій сфері, поглиблення вже сформованих теоретичних та прикладних аспектів функціонування кредитних рейтингових агентств новими науково обгрунтованими положеннями.

Мета статті. Метою дослідження є поглиблення теоретичних положень функціонування кредитних рейтингових агентств та обгрунтування їхньої ролі в розвитку ринку кредитних послуг.

Виклад основного матеріалу. Почнемо дослідження із з'ясування сутності кредитного рейтингового агентства. Одразу зауважимо, що сьогодні питання розвитку таких агентств $є$ досить дискусійним у середовищі науковців та практиків. Це пов'язано з тим, що окреслені установи досить часто неправильно в минулому визначали рейтинги підприємств, держав, що, зрештою, призводило до складних наслідків для розвитку фінансових систем держав і навіть світової економіки. Підтвердженням цього $є$, наприклад, фінансово-економічна криза 2008 року, яку не виявили кредитні рейтингові агентства i не змогли вчасно встановити кризоутворюючі чинники у фінансовій системі США. Проте, з іншого боку, діяльність окреслених установ позитивно впливає на функціону- 
вання всієї фінансової системи світу, дозволяє ефективніше розподіляти ресурси між надійними та більш ризикованими позичальниками, що загалом дозволяє забезпечити розвиток таких систем та підвищити їхню спроможність протидіяти непередбачуваним дисипативним процесам.

Кредитні рейтингові агентства за своєю природою $є$ комерційними установами, які функціонують 3 метою отримання прибутків. Це також одна з причин, чому робота цих організацій піддається критиці, оскільки, враховуючи залежність руху фінансових ресурсів від рейтингу позичальника в межах світової фінансової системи, такі позичальники зацікавлені в підвищенні власного рейтингу. Відповідно кредитні рейтингові агентства можуть зловживати власним становищем і на певних умовах визначати бажані для позичальників рейтинги. Однак насправді така ситуація є складною, враховуючи досить високий рівень конкуренції між кредитними рейтинговими агентствами на ринку відповідних послуг, значну увагу аналітиків у всьому світі до розвитку фінансових ринків та роботи окреслених установ.

Отже, для визначення сутності кредитного рейтингового агентства розглянемо спочатку зміст таких категорій, як «рейтинг», «кредитний рейтинг». Це дозволить чіткіше визначити не лише природу окресленої установи, але і глибше зрозуміти їі функцій та роль у розвитку ринку фінансових послуг. У таблиці 1 представлені підходи науковців до розгляду змісту категорії «рейтинг».

Таблиця 1

Науково-концептуальні підходи до розгляду сутності дефініиії «рейтинг»

\begin{tabular}{|c|c|}
\hline Сутність & Джерело \\
\hline 1 & 2 \\
\hline $\begin{array}{l}\text { Рейтинг - 1) рівень чи шкала, що відображає, } \\
\text { наскільки хорошим, популярним чи важливим є } \\
\text { досліджуваний об’єкт; 2) оцінювання майбутньої } \\
\text { прибутковості інвестицій у визначену компанію; } \\
\text { 3) визначення рівня ризику, пов'язаного із надан- } \\
\text { ням кредиту певній компанії, що обчислюється } \\
\text { спеціалізованою незалежною організацією (рей- } \\
\text { тинговим агентством). }\end{array}$ & $\begin{array}{l}\text { Longman } \begin{array}{l}\text { Business } \\
\text { English }\end{array} \text { Dictionary. } \\
\text { Longman (Pearson Education Limited), } \\
2000.533 \text { p. [16] }\end{array}$ \\
\hline $\begin{array}{l}\text { Рейтинг - визначена в процесі оцінювання фінан- } \\
\text { сова чи кредитна позиція підприємства або } \\
\text { індивідуума. }\end{array}$ & $\begin{array}{l}\text { Oxford Business English Dictionary for } \\
\text { learners of English. Oxford University } \\
\text { Press, 2006. } 616 \mathrm{p} \text {. }\end{array}$ \\
\hline $\begin{array}{l}\text { Рейтинг - 1. Показник оцінки діяльності, популяр- } \\
\text { ності, авторитету якоїсь особи, організації, групи, } \\
\text { програм у певний час, що визначається } \\
\text { соціологічним опитуванням, голосуванням тощо й } \\
\text { визначається місцем, яке вони посідають серед собі } \\
\text { подібних. 2. Відносний показник надійності ділово- } \\
\text { го партнера, банку, страхової компанії тощо. }\end{array}$ & $\begin{array}{l}\text { Великий тлумачний словник сучасної } \\
\text { української мови / [уклад. і голов. ред. } \\
\text { В. Т. Бусел]. Київ; Ірпінь: Перун, } 2005 . \\
\text { VIII, } 1728 \text { с. [2] }\end{array}$ \\
\hline $\begin{array}{l}\text { Під рейтингом розуміється оцінка відносної } \\
\text { надійності корпоративних та муніципальних бор- } \\
\text { гових зобов'язань, що формується залежно від } \\
\text { можливостей емітента сплатити основний борг та } \\
\text { відсотки за ним. }\end{array}$ & $\begin{array}{l}\text { Економічний глосарій економічного фа- } \\
\text { культету Київського національного } \\
\text { університету ім. Т. Г. Шевченка. URL: } \\
\text { http://vocable.ru/dictionary/417/word/\%D0 } \\
\% \mathrm{E} \% \text { E9\%F2\%E8\%ED\%E3 [4] }\end{array}$ \\
\hline $\begin{array}{l}\text { Рейтинг (англ. rating) - оцінка, віднесення до } \\
\text { класу, розряду чи категорії. }\end{array}$ & $\begin{array}{l}\text { Дяків Р. С., Бохан А. В., Горбаль В. М., } \\
\text { Гуриненко О. М. Енциклопедія бізнесме- } \\
\text { на, економіста, менеджера. Київ: } \\
\text { Міжнародна економічна фундація, } 2000 . \\
704 \text { с. [3] }\end{array}$ \\
\hline
\end{tabular}


Закінчення табл. 1

\begin{tabular}{|c|c|}
\hline 1 & 2 \\
\hline $\begin{array}{l}\text { Рейтинг - оцінка значущості, масштабності, важ- } \\
\text { ливості фірми, банку, а також показник, що харак- } \\
\text { теризує кредитоспроможність компанії. }\end{array}$ & $\begin{array}{l}\text { Райзберг Б. А., Лозовский Л. Ш., Старо- } \\
\text { дубцева Е. Б. Современный экономиче- } \\
\text { ский словарь. Москва: Инфра-М, } 2021 . \\
512 \text { с. [12] }\end{array}$ \\
\hline $\begin{array}{l}\text { У словнику розгляд досліджуваного поняття } \\
\text { здійснюється із погляду маркетингу та фінансів. У } \\
\text { першому випадку рейтингом вважається ком- } \\
\text { плексна оцінка, що забезпечує приналежність } \\
\text { об’єкта рейтингування до визначеної кла- } \\
\text { сифікаційної ознаки чи категорії. } 3 \text { погляду } \\
\text { фінансів, рейтинг - це відносний показник, що } \\
\text { відображає рівень надійності ділового партнера, } \\
\text { кредитоспроможності позичальника, надійності } \\
\text { цінних паперів. }\end{array}$ & $\begin{array}{l}\text { Тринько Р., Тринько О. Термінологічний } \\
\text { словник ринкової економіки: гло- } \\
\text { балізація, м маркетинг, статистика, } \\
\text { страхування, фінанси. Львів: Українські } \\
\text { технології 2006, } 216 \text { с. [13] }\end{array}$ \\
\hline $\begin{array}{l}\text { Рейтинг - 1) незалежна оцінка якості боргів ком- } \\
\text { панії; 2) показник ступеня ризику надання креди- } \\
\text { ту тим чи іншим фірмам чи приватним особам, } \\
\text { що дає можливість зробити висновок про доціль- } \\
\text { ність встановлення з ними ділових зв'язків та ви- } \\
\text { дачі позик (так званий кредитний рейтинг). }\end{array}$ & $\begin{array}{l}\text { Коломойцев В. Е. Універсальний слов- } \\
\text { ник економічних термінів: інвестування, } \\
\text { конкуренція, менеджмент, маркетинг, } \\
\text { підприємництво: навч. посіб. Київ: Мо- } \\
\text { лодь, 2000. } 382 \text { с. [8] }\end{array}$ \\
\hline
\end{tabular}

Джерело: складено авторами.

Таким чином, дані табл. 1 дають підстави зробити висновок, що рейтинг - це насамперед оцінка, яка визначається в процесі оцінювання певних певної сукупності показників. Зауважимо, що окреслена дефініція використовується досить активно в різних науках та загалом у повсякденному житті. Однак саме в межах ринку фінансових послуг поняття рейтингу набуває власного, специфічного значення. Саме в межах фінансової науки рейтинги передусім розглядають як спосіб визначення фінансового стану в певний момент часу. Окреслені види рейтингів $є$ досить складними за своїм визначенням, враховуючи значну кількість фінансових та економічних показників. При цьому до їхньої структури можуть відноситися як кількісні, так і якісні показники. Особливу роль рейтинги відіграють у сфері функціонування фінансового ринку та окремих його компонентів. Оцінювання роботи банківських установ, інших фінансових компаній та їхніх потенційних клієнтів, які бажають отримати кредитні, інвестиційні кошти, є однієї 3 найпоширеніших функцій рейтингових агентств.

Для розуміння сутності рейтингу варто розуміти та розрізняти відмінність між такими показниками, як «рейтинг», «ренкінг» та «індекс». Насамперед:

1) рейтинг - комплексне оцінювання стану суб'єкта, віднесення господарюючого суб'єкта до класу або категорії на основі такої оцінки;

2) ренкінг - список господарюючих суб'єктів, які розподілені за величиною якогонебудь одного показника їх діяльності;

3) індекс - зміна кількісного значення певного показника в часі.

Зазначимо, що та економічній науці використовують всі окреслені категорії. Проте, саме рейтингам надається вагома увага при визначенні критичних показників, які дають змогу приймати рішення про здійснення подальших вкладень фінансових ресурсів. Саме високий рівень кореляції між роботою рейтингових агентств та подальшим фінансовим станом кредитних та інвестиційних установ визначає підвищений інтерес таких установ до роботи зазначених агентств, оцінювання їхньої роботи та, що найбільш важ- 
ливіше, формування довіри до встановлених рейтингів. 3 іншого боку, робота рейтингових агентств $\epsilon$ важливою для забезпечення стабільності фінансової системи окремих країн, а тому їх діяльність постійно перебуває в полі зору органів державної влади, які здійснюють нагляд за роботою цих агентств.

Таким чином, під рейтингом будемо розуміти проведену рейтинговим агентством комплексну оцінку стану господарюючого суб'єкта та віднесення його за результатами такої оцінки до певної категорії в певний момент або проміжок часу.

Загалом сьогодні прийнято виділяти серед всіх рейтингів:

1) кредитні рейтинги;

2) інші (некредитні) рейтинги.

Досить часто в науковій літературі трапляється ототожнення понять «рейтинг» та «кредитний рейтинг», що із сутнісної позиції $є$ не зовсім правильним. Розглянемо більш детально зміст категорії «кредитний рейтинг». Відповідні підходи до розуміння цієї дефініції представлені в табл. 2.

Таблиця 2

Науково-концептуальні підходи до розгляду сутності дефініції «кредитний рейтинг»

\begin{tabular}{|c|c|}
\hline Сутність & Джерело \\
\hline 1 & 2 \\
\hline $\begin{array}{l}\text { Кредитний рейтинг умовний вираз кредитоспро- } \\
\text { можності об'єкта рейтингування в цілому та/або } \\
\text { його окремого боргового зобов'язання за націо- } \\
\text { нальною шкалою кредитних рейтингів. }\end{array}$ & $\begin{array}{l}\text { Про державне регулювання ринку } \\
\text { цінних паперів в Україні: Закон України } \\
\text { від 30.10.1996 № 448/96-BP. URL: } \\
\text { https://zakon.rada.gov.ua/laws/show/448/96 } \\
\text {-\%D0\%B2\%D1\%80\#Text [11] }\end{array}$ \\
\hline $\begin{array}{l}\text { Кредитний рейтинг - це універсальний інстру- } \\
\text { мент для оцінки кредитоспроможності позичаль- } \\
\text { ника, надійності його боргових зобов'язань і вста- } \\
\text { новлення плати за відповідний кредитний ризик. }\end{array}$ & $\begin{array}{l}\text { Агентство «Кредит-Рейтинг». URL: } \\
\text { www.credit-rating.ua [1] }\end{array}$ \\
\hline $\begin{array}{l}\text { Кредитний рейтинг є висновком щодо кредитного } \\
\text { ризику. Встановлені рейтинги ідентифікують по- } \\
\text { гляди агентства щодо здатності та готовності } \\
\text { емітента виконати взяті фінансові зобов'язання } \\
\text { своєчасно й у повному обсязі }\end{array}$ & $\begin{array}{l}\text { Standard and Poor's. URL: } \\
\text { https://www.spglobal.com/ratings/en/about/ } \\
\text { understanding-credit-ratings [20] }\end{array}$ \\
\hline $\begin{array}{l}\text { Кредитний рейтинг (Credit raiting) - це оцінка } \\
\text { ймовірності того, що приватна особа, фірма або } \\
\text { країна зможе і захоче розплатитися за своїми бор- } \\
\text { гами. }\end{array}$ & $\begin{array}{l}\text { Nigar Hashimzade, John Black, Gareth } \\
\text { Myles. A Dictionary of Economics. Oxford } \\
\text { University Press, Jan 11, 2017. } 584 \text { p. [17] }\end{array}$ \\
\hline $\begin{array}{l}\text { Рейтинг кредитний - оцінка кредитоспромож- } \\
\text { ності позичальника, надійності його зобов'язань; } \\
\text { може являти собою комбінацію букв (залежно від } \\
\text { рівня ризику) або спеціально розраховується ін- } \\
\text { декс. }\end{array}$ & $\begin{array}{l}\text { Нечаев В. И., Михайлушкин П. В. Эко- } \\
\text { номический словарь: справочное изда- } \\
\text { ние. Краснодар: Просвещение-Юг, } 2011 . \\
463 \text { с. [10] }\end{array}$ \\
\hline $\begin{array}{l}\text { кредитний рейтинг - це міра, яка відображає кре- } \\
\text { дитоспроможність приватної особи, підприєм- } \\
\text { ства, регіону чи країни, а також надійність цінних } \\
\text { паперів. Такі рейтинги розраховуються на основі } \\
\text { минулого й поточного фінансового стану об'єктів } \\
\text { рейтингування, а також оцінок їхньої власності й } \\
\text { узятих боргів }\end{array}$ & $\begin{array}{l}\text { Коваленко Н. FITCH, S\&P, MOODY'S: } \\
\text { кто ставит оценки банкам? 2008. URL: } \\
\text { http://www.prostobank.ua/depozity/stati/fitc } \\
\text { h_s_p_moody_s_kto_stavit_otsenki_banka } \\
\text { m [7] }\end{array}$ \\
\hline
\end{tabular}


Закінчення табл. 2

\begin{tabular}{|c|c|}
\hline 1 & 2 \\
\hline $\begin{array}{l}\text { Кредитний рейтинг являє собою незалежну } \\
\text { суб'єктивну якісну оцінку, якою інвестори керу- } \\
\text { ються при визначенні ступеня довіри кредитору } \\
\text { та яка допомагає приймати рішення про здійснен- } \\
\text { ня інвестицій }\end{array}$ & $\begin{array}{l}\text { Кредитный рейтинг государственных } \\
\text { ценных бумаг Украины. URL: } \\
\text { http://www.minfin.gov.ua/control/ru/publis } \\
\text { h/printable_article?art_id=39188 [9] }\end{array}$ \\
\hline $\begin{array}{l}\text { Кредитні рейтинги - це думка рейтингового } \\
\text { агентства про кредитоспроможність об'єкта рей- } \\
\text { тингування загалом та/чи відносно його окремого } \\
\text { боргового зобов'язання або іншого фінансового } \\
\text { інструменту, виражена у вигляді оцінки за шка- } \\
\text { лою кредитних рейтингів }\end{array}$ & $\begin{array}{l}\text { Regulation (EC) № 1060/2009 of the Euro- } \\
\text { pean Parliament and of the Council of } 16 \\
\text { September } 2009 \text { on credit rating agencies. } \\
\text { URL: } \\
\text { lex.ttp://eur- } \\
\text { ri=OJ:L:2009:302:0001:0031:EN:PDF [19] }\end{array}$ \\
\hline
\end{tabular}

Джерело: складено авторами.

Отже, враховуючи підходи до розгляду сутності категорії «кредитний рейтинг» під цієї дефініцією будемо розглядати оцінку, яка характеризує частково фінансовий стан рейтингованої особи, визначає показник іiї кредитоспроможності, фінансової стійкості та здатності виконувати в майбутньому взяті на себе додаткові фінансові зобов'язання. Зауважимо, що така оцінка заснована на вивченні всієї доступної інформації про сумарні активи та зобов'язання позичальника, ступінь ризику і його кредитну історію (дані про своєчасність платежів відсотків і виплат в рахунок погашення основної суми боргу в минулому). Приватним особам, фірмам і державам із високим кредитним рейтингом набагато простіше й дешевше отримати грошовий або товарний кредит, ніж позичальникам з низьким кредитним рейтингом [17].

Кредитне рейтингове агентство, у свою чергу, - організація, яка присвоює кредитні рейтинги, які показують здатність боржника повернути борг, своєчасно сплачуючи нараховані відсотки, а також ймовірність дефолту боржника. Найкращим чином обгрунтувати сутність кредитних рейтингових агентств можливо через виокремлення основних функцій, які є для них притаманними. До їх переліку варто віднести такі:

1) створення аналітичної інформації - кредитні рейтингові агентства у своїй діяльності використовують значну кількість інформації з різних джерел, проводять іiі дослідження і створюють нові, узагальнені дані, які є зручними для використання вже фінансовими установами та іншими аналітичними організаціями;

2) зниження витрат - враховуючи, що кредитні рейтингові агентства оприлюднюють результати власних досліджень, то фінансові установи, у тому числі банки, мають змогу використовувати їх у своїй діяльності, не створюю власних підрозділів для отримання таких даних; це дозволяє таким установам не лише знизити власні функції, але і сфокусуватися виключно на власній діяльності;

3) підвищення репутації - кредитний рейтинг є показником фінансового стану підприємства, його фінансової міцності та спроможності залучати додаткові фінансові ресурси для власного розвитку; саме це робить такі рейтинги показником репутації підприємств, засвідчує також ефективність управління ними, свідчить про інноваційність їхнього розвитку;

4) підвищення транспарентності - кредитні рейтингові агентства, створюючи відповідні рейтинги, забезпечують загалом інформацією всіх учасників на ринку кредитних послуг, що дозволяе кожному з них приймати відповідні рішення щодо надання позик, вкладенні інвестицій і т. ін.; загалом це приводить до поступового підвищення інформаційної прозорості роботи фінансових установ;

5) зниження системного кредитного ризику - визначення кредитних рейтингів дозволяє у межах усього ринку кредитних послуг правильно встановити рівень кредитоспроможності позичальників, оцінити їхню можливість вчасно обслуговувати взяті позики; це 
допомагає банківським установам, інвестиційним компаніям як правильно оцінити ризик за конкретними кредитними операціями, так і вартість позикових коштів; це все в підсумку дозволяє знизити системний кредитний ризик національної економіки та підвищити рівень її стійкості до впливу негативних ендогенних та екзогенних чинників;

6) консультативна допомога - окремі становлення кредитних рейтингів значна кількість кредитних рейтингових агентств надає суб'єктам підприємницької діяльності додаткові послуги у сфері фінансового консалтингу, готують відповідні аналітичні звіти щодо розвитку окремих галузей та сфер національного господарства, світові ринки товарів і послуг на замовлення клієнтів;

7) функція розвитку - враховуючи наявність значного впливу на розвиток ринку кредитних послуг, фінансову систему країни, кредитні рейтингові агентства сприяють загальному розвитку економічних відносин у країні, дозволяють ефективно розподіляти потоки фінансових ресурсів, сприяють підвищенню ефективності роботи кредитних та інвестиційних установ.

Індустрія кредитних рейтингів формувалася в умовах загальної зацікавленості в перетворенні великого обсягу розрізненої фінансової інформації в просту і ясну оцінку кредитоспроможності боржників - кредитний рейтинг. У США практика присвоєння кредитних рейтингів емітентів боргових зобов'язань налічує вже понад сто років, у той час як європейський і національні ринки кредитно-рейтингових послуг отримали розвиток лише в останні два десятиліття. У табл. 3 представлена інформація про найбільш відомі світові кредитні рейтингові агентства.

Таблиця 3

Інформація про основних світових лідерів у сфері присвоєння кредитних рейтингів

\begin{tabular}{|c|c|c|}
\hline Агентство & $\begin{array}{c}\text { Рік } \\
\text { заснування }\end{array}$ & Функції \\
\hline $\begin{array}{l}\text { Standard \& } \\
\text { Poors }\end{array}$ & $\begin{array}{c}1860 \text { р., } \\
\text { Нью-Йорк }\end{array}$ & $\begin{array}{l}\text { Вважається одним із найбільш професійних дослідників світо- } \\
\text { вого майданчика. Оціночна діяльність Standard \& Poors здійс- } \\
\text { нюється не тільки на загальному, але й на національному рівні. } \\
\text { Воно проводить дослідження на внутрішньому і зовнішньому } \\
\text { ринках, після чого виносить об'єктивне судження про їхні фі- } \\
\text { нансові можливості. } \\
\text { У число обов'язків Standard \& Poors входить виявлення ризику } \\
\text { переказу коштів за кордон. Фірма-емітент повинна продемон- } \\
\text { струвати хорошу кредитоспроможність і відсутність непога- } \\
\text { шених боргових зобов'язань. }\end{array}$ \\
\hline Moody's & $\begin{array}{c}1909, \\
\text { Нью-Йорк }\end{array}$ & $\begin{array}{l}\text { Головним завданням вважається аналіз біржових ринків і при- } \\
\text { власнення кредитних рейтингів. Оскільки Мооду's займається } \\
\text { національною оцінкою, він розробив } 40 \text { окремих систем для } \\
\text { аналізу різних підрозділів. Установа оцінює галузі, країни, під- } \\
\text { приємства та інші групи. Залежно від предмета аналізу, фахівці } \\
\text { застосовують певну систему, що дозволяє провести повноцінне } \\
\text { дослідження. }\end{array}$ \\
\hline Fitch Ratings & $\begin{array}{c}1913, \\
\text { Нью-Йорк, } \\
\text { Лондон }\end{array}$ & $\begin{array}{l}\text { Здійснює незалежний аналіз кредитних ринків і учасників сис- } \\
\text { теми. Воно вивчає платоспроможність і надійність кожної ор- } \\
\text { ганізації, після чого складає загальний список. У 1924-му кері- } \\
\text { вництво ввело оціночну шкалу з додаванням проміжних рівнів. } \\
\text { Fitch Ratings прославився у ролі аналітика, що створює докла- } \\
\text { дні звіти із зазначенням всіляких нюансів. }\end{array}$ \\
\hline
\end{tabular}

Джерело: складено авторами. 
ФІНАНСОВІ РЕСУРСИ: ПРОБЛЕМИ ФОРМУВАННЯ ТА ВИКОРИСТАННЯ

Висновки і пропозиції. Таким чином, у результаті проведення дослідження було встановлено, що кредитні рейтингові агентства на сьогодні є невід'ємною частиною розвитку ринку кредитних послуг та загалом всієї фінансової системи будь-якої розвинутої країни. У статті розглянуто сутність таких категорій, як «рейтинг» та «кредитний рейтинг», виокремлені окремі наукові підходи до розгляду цих дефініцій. У підсумку рейтинг запропоновано розглядати як проведене рейтинговим агентством комплексне оцінювання стану господарюючого суб'єкта та віднесення його за результатами такої оцінки до певної категорії в певний момент або період часу.

У свою чергу, сутність кредитного рейтингу визначено таким чином: кредитний рейтинг - оцінка, яка характеризує частково фінансовий стан рейтингованої особи, визначає показник іiі кредитоспроможності, фінансової стійкості та здатності виконувати у майбутньому взяті на себе додаткові фінансові зобов'язання. Також було обгрунтовано функції кредитних рейтингових агентств та констатовано важливість їх функціонування для формування сприятливих умов для розвитку фінансових установ, забезпечення їх стійкості та надійності функціонування. Подальші наукові дослідження у сфері визначення кредитних рейтингових агентств можуть бути пов'язані з вивченням трансформаційних процесів у роботі таких організацій, які обумовлюються на сьогодні активним впровадженням сучасних цифрових технологій у діяльність кредитних установ, підвищенням якості автоматичної обробки фінансової інформації.

\section{Список використаних джерел}

1. Агентство «Кредит-Рейтинг». URL: www.credit-rating.ua.

2. Великий тлумачний словник сучасної української мови / [уклад. і голов. ред. В. Т. Бусел]. Київ; Ірпінь: Перун, 2005. VIII, 1728 с.

3. Дяків Р. С., Бохан А. В., Горбаль В. М., Гуриненко О. М. Енциклопедія бізнесмена, економіста, менеджера. Київ : Міжнародна економічна фундація, 2000. 704 с.

4. Економічний глосарій економічного факультету Київського національного університету ім. Т. Г. Шевченка. URL: http://vocable.ru/dictionary/417/word/\%D0\%E5\%E9\%F2\%E8\%ED\%E3.

5. Кичко I. I. Елементи системного підходу до управління та фінансування соціальної сфери. Украӥна: аспекти прачіi. 2006. № 2. С. 17-21.

6. Кичко I. I. Особисті потреби: регуляторні механізми формування та забезпечення. Чернігів : Чернігівський державний інститут права, соціальних технологій та праці, 2010. 258 с.

7. Коваленко H. FITCH, S\&P, MOODY'S: кто ставит оценки банкам? 2008. URL: http://www.prostobank.ua/depozity/stati/fitch_s_p_moody_s_kto_stavit_otsenki_bankam.

8. Коломойцев В. Е. Універсальний словник економічних термінів: інвестування, конкуренція, менеджмент, маркетинг, підприємництво : навч. посіб. Київ : Молодь, 2000. 382 с.

9. Кредитный рейтинг государственных ценных бумаг Украины. URL: https://mof.gov.ua/ uk/kreditnij-rejting-potochni-rejtingi-zagalna-informacija-istorichni-zmini.

10. Нечаев В. И., Михайлушкин П. В. Экономический словарь: справочное издание. Краснодар : Просвещение-Юг, 2011. 463 с.

11. Про державне регулювання ринку цінних паперів в Україні : Закон України від 30.10.1996 № 448/96-BP. URL: https://zakon.rada.gov.ua/laws/show/448/96-\%D0\%B2\%D1\%80\#Text.

12. Райзберг Б. А., Лозовский Л. Ш., Стародубцева Е. Б. Современный экономический словарь. Москва : Инфра-М, 2021. 512 с.

13. Тринько Р., Тринько О. Термінологічний словник ринкової економіки: глобалізація, маркетинг, статистика, страхування, фінанси. Львів : Українські технології, 2006, 216 с.

14. Холявко Н. І. Сучасні інформаційні технології в роботі фінансових установ. Бізнес Інформ. 2021. № 5. C. 152-161.

15. Холявко Н. І., Колоток М. О. Інформаційні технології в роботі зарубіжних фінансових установ. Проблеми і перспективи економіки та управління. 2021. № 1 (25). С. 117-126.

16. Longman Business English Dictionary. Longman (Pearson Education Limited), 2000. 533 p. 
17. Nigar Hashimzade, John Black, Gareth Myles. A Dictionary of Economics. Oxford University Press, Jan 11, 2017. 584 p.

18. Oxford Business English Dictionary for learners of English. Oxford University Press, 2006. $616 \mathrm{p}$.

19. Regulation (EC) № 1060/2009 of the European Parliament and of the Council of 16 September 2009 on credit rating agencies. URL: http://eur-lex.europa.eu/LexUriServ/LexUriServ.do?uri= OJ:L:2009:302:0001:0031:EN:PDF.

20. Standard and Poor's. URL: https://www.spglobal.com/ratings/en/about/understandingcredit-ratings.

\section{References}

1. Ahentstvo «Kredyt-Reitynh» [Credit Rating Agency]. (n.d.). www.credit-rating.ua.

2. Busel, V.T. (2005). Velykyi tlumachnyi slovnyk suchasnoi ukrainskoi movy [Large explanatory dictionary of the modern Ukrainian language]. Perun.

3. Diakiv, R.S., Bokhan, A.V., Horbal, V.M., \& Hurynenko, O.M. (2000). Entsyklopediia biznesmena, ekonomista, menedzhera [Encyclopedia of a businessman, economist, manager]. Mizhnarodna ekonomichna fundatsiia.

4. Ekonomichnyi hlosarii ekonomichnoho fakultetu Kyivskoho natsionalnoho universytetu im. T. H. Shevchenka [Economic Glossary of the Faculty of Economics of T.G. Shevchenko Kyiv National University] (n.d.). http://vocable.ru/dictionary/417/word/\%D0\%E5\%E9\%F2\%E8\%ED\%E3.

5. Kychko, I.I. (2006). Elementy systemnoho pidkhodu do upravlinnia ta finansuvannia sotsialnoi sfery [Elements of a systematic approach to management and financing of the social sphere]. Ukraina: aspekty pratsi-Ukraine: aspects of work, (2), 17-21.

6. Kychko, I.I. (2010). Osobysti potreby: rehuliatorni mekhanizmy formuvannia ta zabezpechennia [Personal needs: regulatory mechanisms of the formation and provision]. Chernihivskyi derzhavnyi instytut prava, sotsialnykh tekhnolohii ta pratsi.

7. Kovalenko, N. (2008). FITCH, S\&P, MOODYS: kto stavyt otsenky bankam? URL: http://www.prostobank.ua/depozity/stati/fitch_s_p_moody_s_kto_stavit_otsenki_bankam.

8. Kolomoitsev, V.E. (2000). Universalnyi slovnyk ekonomichnykh terminiv: investuvannia, konkurentsiia, menedzhment, marketynh, pidpryiemnytstvo [Universal dictionary of economic terms: investment, competition, management, marketing, entrepreneurship]. Molod.

9. Kredytnyi reiting gosudarstvennykh tsennykh bumah Ukrainy [Credit rating of government securities of Ukraine]. (n.d.). https://mof.gov.ua/uk/kreditnij-rejting-potochni-rejtingi-zagalnainformacija-istorichni-zmini.

10. Nechaev, V.Y., \& Mykhailushkyn, P.V. (2011). Ekonomicheskyi slovar: spravochnoe izdanie [Economic Dictionary: reference edition]. Prosveshchenie-Iuh.

11. Pro derzhavne rehuliuvannia rynku tsinnykh paperiv v Ukraini [On State Regulation of Securities Market in Ukraine], Law of Ukraine № 448/96-BP (on October 30, 1996). https://zakon.rada.gov.ua/laws/show/448/96-\%D0\%B2\%D1\%80\#Text.

12. Raizberh, B.A., Lozovskyi, L.Sh., \& Starodubtseva, E.B. (2021). Sovremennyi ekonomicheskii slovar [Modern economic dictionary]. Infra-M.

13. Trynko, R., \& Trynko, O. (2006). Terminolohichnyi slovnyk rynkovoi ekonomiky: hlobalizatsiia, marketynh, statystyka, strakhuvannia, finansy [Terminological dictionary of market economy: globalization, marketing, statistics, insurance, finance]. Ukrainski tekhnolohii.

14. Kholiavko, N.I. (2021). Suchasni informatsiini tekhnolohii v roboti finansovykh ustanov [Modern information technology in the work of financial institutions]. Biznes Inform - Business Inform, (5), 152-161.

15. Kholiavko, N.I., \& Kolotok, M.O. (2021). Informatsiini tekhnolohii v roboti zarubizhnykh finansovykh ustanov [Information technology in the work of foreign financial institutions]. Problemy $i$ perspektyvy ekonomiky ta upravlinnia - Problems and prospects of economics and management, (1(25)), 117-126.

16. Longman Business English Dictionary. (2000). Longman (Pearson Education Limited). 
ФІНАНСОВІ РЕСУРСИ: ПРОБЛЕМИ ФОРМУВАННЯ ТА ВИКОРИСТАННЯ

17. Nigar, Hashimzade, John, Black, Gareth, Myles. (2017). A Dictionary of Economics. Oxford University Press.

18. Oxford Business English Dictionary for learners of English. (2006). Oxford University Press.

19. Regulation (EC) № 1060/2009 of the European Parliament and of the Council of 16 September 2009 on credit rating agencies. http://eur-lex.europa.eu/LexUriServ/LexUriServ.do?uri= OJ:L:2009:302:0001:0031:EN:PDF.

20. Standard and Poor's. https://www.spglobal.com/ratings/en/about/understanding-credit-ratings.

Дубина Максим Вікторович - доктор економічних наук, професор, завідувач кафедри фінансів, банківської справи та страхування, Національний університет «Чернігівська політехніка» (вул. Шевченка, 95, м. Чернігів, 14035, Україна).

Dubyna Maksym - Doctor of Economics, Professor, Head of Department of Finance, Banking and Insurance, Chernihiv Polytechnic National University (95 Shevchenka Str., 14035 Chernihiv, Ukraine).

E-mail: maksim-32@ukr.net

ORCID: http://orcid.org/0000-0002-5305-7815

ResearcherID: F-3291-2014

Островська Наталія Степанівна - доктор економічних наук, доцент, доцент кафедри публічних, корпоративних фінансів та фінансового посередництва, Чернівецький національний університет імені Юрія Федьковича (вул. Коцюбинського, 2, м. Чернівці, 58012, Україна).

Ostrovska Natalia - Doctor of Economics, Associate Professor, Associate Professor at the Department of Public, Corporate Finance and Financial Intermediation, Yuriy Fedkovych Chernivtsi National University (2 Kotsiubinskyi Str., 58012, Chernivtsi, Ukraine).

E-mail: n.ostrovska@chnu.edu.ua

ORCID: https://orcid.org/0000-0002-7259-7403

ResearcherID: https://publons.com/researcher/3342699/natalia-ostrovska

Scopus Author ID: 56606207800

Мурашковська Ірина Анатоліївна - аспірантка кафедри фінансів, банківської справи та страхування, Національний університет «Чернігівська політехніка» (вул. Шевченка, 95, м. Чернігів, 14035, Україна).

Murashkovska Iryna - PhD Student of Department of Finance, Banking and Insurance, Chernihiv Polytechnic

National University (95 Shevchenka Str., 14035 Chernihiv, Ukraine). 